\title{
PENGARUH DIMENSI KUALITAS PRODUK TERHADAP KEPUASAN KONSUMEN VENICE PURE AESTHETIC CLINIC SALATIGA
}

\author{
Dayinta Tiara Kusuma ${ }^{1}$, Hardi Utomo² \\ Sekolah Tinggi Ilmu Ekonomi AMA Salatiga \\ Corresponding author: hardiutomo@stieama.ac.id
}

\begin{abstract}
ABSTRAK
Klinik Kecantikan Venice menyediakan berbagai produk perawatan kulit dan tubuh bagi masyarakat Kota Salatiga. Dalam menunjang kegiatannya, Venice Pure Aesthetic Clinic didukung oleh karyawan-karyawan yang professional, semua itu untuk memberikan kepuasan kepada konsumennya. Namun sejak bulan Januari 2017 s/d Juli 2020 jumlah konsumen yang datang ke klinik mengalami fluktuasi dalam jumlah yang cukup besar. Dugaan peneliti kondisi tersebut disebabkan karena kualitas produk yang ditawarkan kepada konsumen. Hal inilah yang menarik peneliti untuk melakukan penelitian secara mendalam tentang pengaruh dimensi kualitas produk terhadap kepuasan konsumen Venice Pure Aesthetic Clinic Salatiga.

Tujuan dari penelitian ini adalah untuk mengetahui pengaruh performance, feature, reliability, conformance, durability, serviceability, aesthetics, dan perceived quality secara simultan terhadap kepuasan konsumen di Venice Pure Aesthetic Clinic Salatiga.

Tipe penelitian dalam penulisan skripsi ini adalah eksplanatori. Data primer diperoleh dengan membagikan kuesioner kepada responden, sedang data sekunder diperoleh dari catatan administrasi Venice Pure Aesthetic Clinic, serta buku-buku yang menunjang. Populasi penelitian ini adalah seluruh konsumen yang menggunakan produk dan jasa di Venice Pure Aesthetic Clinic, sedang jumlah sampelnya adalah 97 orang yang menggunakan produk dan jasa di Venice Pure Aesthetic Clinic. Alat analisis data yang digunakan adalah regresi linier berganda.

Hasil penelitian menunjukkan, 1) Performance, feature, reliability, conformance, durability, serviceability, aesthetics, dan perceived quality secara parsial maupun simultan berpengaruh signifikan terhadap kepuasan konsumen. Hal tersebut dibuktikan nilai $t$-hitung masing-masing variabel > $t$-tabel $(1,987)$, dan nilai $F_{\text {hitung }}(313,479)>$ $\left.F_{\text {tabel }}(2,05), 2\right)$ Nilai Adjusted $R$ Square adalah sebesar 0,963, berarti variabel performance $(X 1)$, feature $(X 2)$, reliability $(X 3)$, conformance $(X 4)$, durability $(X 5)$, serviceability $(X 6)$, aesthetics $(X 7)$, dan perceived quality $(X 8)$ mampu menjelaskan kepuasan konsumen $(Y)$ sebesar 96,30\%, dan sisanya 3,70\% dijelaskan oleh variabel lainnya yang tidak diteliti, seperti: biaya pelanggan, emosional pelanggan, kepercayaan produk, lokasi, dan kualitas pelayanan.

Saran yang dapat diberikan adalah pihak manajemen perlu lebih selektif dalam memilih produk kecantikan yang dijualnya, meningkatkan kemampuan petugas dalam melakukan pelayanan, menyediakan produk lebih beragam, memperbaiki sistem pengecekan produk, mengikutkan dokter dalam pelatihan-pelatihan, mengganti distributor produk, dan melakukan rapat singkat sebelum pekerjaan dimulai.
\end{abstract}

Kata Kunci : Kualitas produk, kepuasan konsumen 


\section{PENDAHULUAN}

Saat ini banyak masyarakat yang memperhatikan pentingnya menjaga penampilan dari dalam maupun dari luar, mulai dari kalangan remaja maupun dewasa, baik dari jenis kelamin wanita maupun laki-laki. Penampilan dari luar lebih pada masalah berpakaian, dan hal-hal lainnya yang kelihatan untuk dipandang yang berkaitan dengan tren, sementara penampilan dari dalam terkait dengan menjaga kesehatan, seperti: menjaga kesehatan kulit wajah dan tubuh, sehingga tampil lebih percaya diri.

Klinik kecantikan merupakan salah satu bentuk jasa hibrid, dimana penawaran terdiri dari barang dan jasa yang sama besar porsinya (Tjiptono, 2016:6). Artinya untuk memberikan kepuasan kepada konsumennya, selain memberikan pelayanan yang berkualitas kepada konsumennya, pihak penyelenggara bisnis tersebut harus benar-benar memiliki pengetahuan dan keterampilan yang memadai dalam mengaplikasikan produkproduk perawatan kulit dan tubuh yang ditawarkan, agar produk-produk yang ditawarkan tersebut memuaskan kosumennya. Hal tersebut sejalan pendapat Hayati dan Sutarji (2015:50), dimana dengan adanya kualitas produk yang baik akan membuat para konsumen puas yang pada akhirnya akan mengakibatkan terjadinya pembelian ulang atau kesetiaan konsumen secara berkelanjutan.

Kualitas produk sendiri merupakan keseluruhan ciri dari suatu produk atau pelayanan pada kemampuan untuk memuaskan kebutuhan yang dinyatakan atau tersirat (Kotler, 2018:49). Untuk menentukan sejauhmana kualitas produk, maka terdapat 8 (delapan) yang dapat digunakan sebagai acuan, yakni: Performance, feature, reliability, conformance, durability, serviceability, aesthetics, dan perceived quality (Kotler, 2018:361). Jika dimensi-dimensi tersebut dinilai baik oleh konsumen, maka produk dinilai berkualitas, begitu pula sebaliknya jika banyak dimensi-dimensi produk tersebut dinilai buruk, maka produk dinilai memiliki kualitas yang buruk.

Performance merupakan aspek fungsional yang terdapat pada produk dan menjadi karakteristik utama pelanggan dalam membeli barang. Sehingga konsumen menilai baik atau tidaknya produk yang ditawarkan dan dirasakan melalui kemampuan produk dalam menjalankan fungsi utamanya. Feature sebagai dimensi yang berkaitan dengan aspek performasi yang mendukung fungsi dasar suatu produk dan berkaitan dengan pilihan produk dan pengembangannya. Reliability pada intinya adalah peluang suatu produk bebas dari kegagalan produk saat menjalankan fungsinya, artinya dimensi ini terkait dengan konsistensi kinerja produk. Conformance adalah kesesuaian kinerja produk dengan standar yang dinyatakan pada suatu produk. Ini semacam janji yang harus dipenuhi oleh produk (Kotler, 2018:361).

Durability menunjukkan usia produk, yaitu jumlah pemakaian suatu produk sebelum produk itu digantikan atau rusak. Semakin lama daya tahannya tentu produk dinilai semakin awet, sehingga produk akan dipresepsikan lebih berkualitas. Serviceability merupakan sejauhmana produk tersebut dapat diperbaiki. Sesuai dengan maknanya, disini kualitas produk ditentukan atas dasar kemampuan diperbaiki: mudah, cepat, dan kompeten. Aesthetic menyangkut tampilan produk yang membuat konsumen suka. Intinya aesthetic menyangkut penyajian produk yang bisa dinilai dengan panca indera (rasa, aroma, suara, dan seterusnya). Sementara perceived quality berkaitan dengan penilaian konsumen terhadap citra, merek, atau iklan serta tanggung jawab perusahaan. Produk- produk yang bermerek terkenal biasanya dipersepsikan lebih berkualitas dibanding merek- merek yang tidak terdengar, sehingga setiap produk selalu berupaya membangun mereknya agar memiliki brand equity yang tinggi (Kotler, 2018:361). 
Venice Pure Aesthetc Clinic merupakan salah satu dari 4 (empat) salon kecantikan yang berada di Kota Salatiga. Venice Pure Aesthetic Clinic berdiri pada tahun 2014 yang beralamat di J1. Imam Bonjol No.30 Salatiga. Klinik Kecantikan Venice menyediakan berbagai produk perawatan kulit dan tubuh bagi masyarakat Kota Salatiga. Dalam menunjang kegiatannya, saat ini Venice Pure Aesthetic Clinic didukung oleh karyawan- karyawan yang professional, 1 orang manajer, 1 orang dokter, dan 10 karyawan. Semua itu untuk memberikan kepuasan kepada konsumennya. Berikut perkembangan jumlah konsumen yang datang untuk membeli produk, dan mendapatkan perawatan kulit wajah dan perawatan tubuh di Venice Pure Aesthetic Clinic Salatiga.

Tabel 1

Perkembangan Jumlah Konsumen Tahun Januari 2017-Juli 2020

\begin{tabular}{clc}
\hline Tahun & \multicolumn{1}{c}{ Bulan } & Jumlah (Orang) \\
\hline \multirow{2}{*}{2017} & Januari - April Mei - & 450 \\
& Agustus September - & 650 \\
& Desember & 735 \\
\multirow{2}{*}{2018} & Januari - April Mei - & 500 \\
& Agustus September - & 650 \\
& Desember & 700 \\
& Januari - April Mei - & 400 \\
\multirow{2}{*}{2020} & Agustus September - & 500 \\
& Desember & 800 \\
& Januari - April & 520 \\
& Mei - Juli & 610 \\
\hline
\end{tabular}

Sumber : Data sekunder yang diolah, tahun 2020

Pada tabel 1 tersebut secara jelas menunjukkan, bahwa jumlah konsumen yang datang ke klinik kecantikan selama bulan Januari 2017 s/d Juli 2020 berfluktuasi, bahkan dapat dikatakan fluktuasi yang terjadi cenderung besar. Hal inilah yang menarik peneliti untuk melakukan penelitian secara mendalam tentang fenomena tersebut, khususnya dikaitkan dengan kualitas produk yang ditawarkan kepada konsumen. Sebab bagaimanapun sebagai usaha yang bergerak dibidang jasa yang sangat tergantung dengan penuh oleh penggunaan produk, maka patut diduga bahwa kondisi yang terjadi tersebut salah satunya karena masalah kualitas produk.

Dugaan tersebut diperkuat oleh hasil observasi yang dilakukan pada tanggal 10 Agustus 2020 dengan melakukan wawancara kepada 15 orang responden dimana $60 \%$ dari responden merasa bahwa produk kecantikan yang dijual Venice Pure Aesthetic Clinic kurang berkualitas baik, pilihan produk yang dijual kurang, pernah membeli produk yang dalam kondisi cacat atau rusak, resep yang diberikan tidak sesuai, daya tahan produk kurang sesuai harapan, petugas dinilai kurang ramah, kebersihan produk kurang terjaga, dan produk yang dibeli kurang sesuai dengan manfaatnya. Namun demikian untuk membuktikan kebenarannya perlu dilakukan penelitian secara mendalam. Untuk itu judul yang diajukan dalam penelitian ini adalah. Berdasarkan penjelasan tersebut maka masalah penelitia yang akan dianalisis adalah pengaruh dimensi kualitas produk terhadap kepuasan konsumen Venice Pure Aesthetic Clinic Salatiga.

\section{LANDASAN TEORI DAN PENGEMBANGAN HIPOTESIS Dimensi kualitas produk}

Kepuasan konsumen dapat dilihat secara tidak langsung melalui penilaian mereka terhadap atribut-atribut atau indicator-indikator yang ada. Atribut-atribut tersebut merupakan cerminan atas produk yang ditawarkan dan diberikan oleh Venice Pure Aesthetic 
Clinic Salatiga. Atribut-atribut tersebut terhimpun didalam suatu dimensi kualitas produk yang terdiri dari dimensiPerformance (kinerja), feature (ciri-ciri produk), reliability (kemudahan perbaikan), conformance (ketepatan atau kesesuaian), durability (ketahanan), serviceability (kemampuan diperbaiki), aesthetics (keindahan tampilan produk), dan perceived quality (kualitas yang dirasakan) (Kotler, 2018:361). Berikut penjelasannya :

a. Performance (kinerja)

Menurut Kotler (2018:361), kinerja merupakan karakteristik inti atau fungsi utama suatu produk. Menurut Tjiptono dan Chandra (2016:130), kinerja adalah aspek fungsional dari produk inti yang dibeli. Kinerja juga dapat didefinisikan dengan karakteristik operasi dasar dari sebuah produk (Mullins, Orville, Larreche, dan Boyd, 2005:422).

b. Feature (ciri-ciri produk)

Feature merupakan karakteristik atau ciri-ciri tambahan yang melengkapi manfaat dasar suatu produk (Kotler, 2018:361). Feature didefinisikan juga sebagai aspek yang menambah fungsi dasar berkaitan dengan pilihan-pilihan dan pengembangan produk (Tjiptono dan Chandra, 2016:130). Definisi lainnya yaitu karakteristik produk yang dirancang untuk menyempurnakan fungsi produk atau ketertarikan konsumen terhadap produk (Mullins, Orville, Larreche, dan Boyd, 2005:422).

c. Reliability (keterandalan)

Keterandalan, yaitu peluang suatu produk bebas dari kegagalan produk saat menjalankan fungsinya, artinya dimensi ini terkait dengan konsistensi kinerja produk dalam kondisi tertentu (Kotler, 2018 :361).

d. Conformance (ketepatan atau kesesuaian)

Conformance adalah kesesuaian kinerja produk dengan standar yang dinyatakan suatu produk. Ini semacam janji yang harus dipenuhi oleh produk (Kotler, 2018:361).

e. Durability (ketahanan)

Daya tahan menunjukkan usia produk, yaitu jumlah pemakaian suatu produk sebelum produk itu digantikan atau rusak (Kotler, 2018:361).

f. Serviceability (kemampuan diperbaiki)

Produk yang mampu diperbaiki tentu kualitasnya lebih tinggi dibanding produk yang tidak atau sulit diperbaiki (Kotler, 2018:361).

g. Aesthetics (keindahan tampilan produk)

Aesthetic dalam hal ini dapat dinilai dengan beberapa indikator, seperti: produk yang ditawarkan dalam kondisi selalu bersih, penyajian produk yang tertata rapi, bentuk dan warna produk yang menarik, dan desain pengaturan tata letak produk yang menarik (Kotler, 2018:361).

h. Perceived quality (kualitas yang dirasakan)

Produk-produk yang bermerek terkenal biasanya dipersepsikan lebih berkualitas dibanding merek-merek yang tidak terdengar. Itulah sebabnya produk selalu berupaya membangun mereknya sehingga memiliki brand equity yang tinggi. Tentu saja ini tidak dapa dibangun semalam karena menyangkut banyak aspek termasuk dimensi kualitas dari kinerja, fitur, daya tahan, dan sebagainya (Kotler, 2018:361). 
Berdasarkan landasan teori tersebut, maka rumusan hipitesisnya dalah sebagai berikut : $\mathrm{H}_{\mathrm{a}}$ : secara parsial terdapat pengaruh signifikan dari variabel performance (X1), feature (X2), reliability (X3), conformance (X4), durability (X5), serviceability (X6), aesthetics $(X 7)$, dan perceived quality $(X 8)$ terhadap kepuasan konsumen $(Y)$.

\section{METODE PENELITIAN}

\section{Populasi dan Sampel}

Menurut Sugiyono (2012:119) populasi adalah keseluruhan dari subjek yang menjadi amatan. Populasi penelitian ini adalah konsumen yang menggunakan produk dan jasa di Venice Pure Aesthetic Clinic. Berdasarkan data bulan Mei - Juli 2020 terdapat konsumen yang menggunakan produk dan jasa di Venice Pure Aesthetic Clinic adalah sebanyak 610 orang. Menurut Sugiyono (2012:119) sampel adalah sebagian dari subjek yang menjadi amatan. Dalam penelitian ini jumlah sampelnya adalah 86 responden. Untuk memperoleh sampel sebanyak 86 orang tersebut, peneliti menggunakan teknik purposive sampling, yaitu teknik pengambilan sampel yang tidak memberi peluang atau kesempatan sama bagi setiap unsur atau anggota populasi untuk dipilih menjadi sampel. Sampel dalam penelitian ini mempunyai kriteria tertentu, adapun kriteria tersebut sebagai berikut: konsumen membeli produk dan melakukan perawatan di Venice Pure Aesthetic Clinic Salatiga, usia minimal responden berusia 17 tahun, karena usia tersebut adalah usia dewasa awal yang dimana banyak berbagai masalah kulit yang muncul.

\section{Analisis Data}

\section{Uji Regresi Linier Berganda}

Alat analisis yang digunakan untuk mengetahui pengaruh performance, feature, reliability, conformance, durability, serviceability, aesthetics, dan perceived quality secara parsial maupun simultan terhadap kepuasan konsumen Venice Pure Aesthetic Clinic Salatiga adalah regresi liner berganda. Persamaan regresi liner berganda dalam penelitian ini adalah

$$
Y=a+\beta_{1} X_{1}+\beta_{2} X_{2}+\beta_{3} X_{3}+\beta_{4} X_{4}+\beta_{5} X_{5}+\beta_{6} X_{6}+\beta_{7} X_{7}+\beta_{8} X_{8}+e
$$

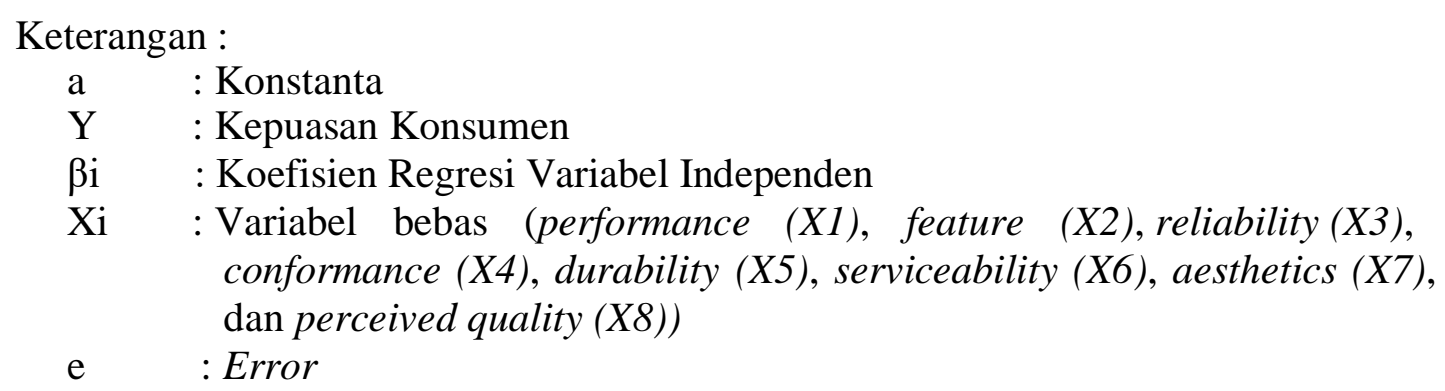

\section{HASIL DAN PEMBAHASAN \\ Hasil Uji Validitas Kuesioner Penelitian}

Uji Validitas digunakan untuk mengukur sejauhmana instrumen penelitian yang digunakan dalam penelitian ini (kuesioner penelitian) layak digunakan sebagai alat pengumpul atau penggalian data di lapangan. Mengetahui hal tersebut, maka data hasil penelitian yang diperoleh dianalisis dengan menggunakan Uji Prearson Product Moment. Kuesioner dikatakan valid jika nilai r-hitungnya $>$ r-tabel. $r$-tabel didapat dari $(\mathrm{df}=86-2=$ $84, \alpha=0,05)$. Berdasarkan data yang sudah diolah bahwa nilai $r$-hitung masing-masing instrumen tiap-tiap variabel penelitian menunjukkan nilai r-hitung $(0,455 \mathrm{~s} / \mathrm{d} 0,959)>\mathrm{r}-$ 
tabel $(0,2)$. Berarti kuesioner penelitian dinyatakan valid, sehingga layak digunakan sebagai sarana mengukur, dan mengungkap data variabel penelitian secara tepat.

\section{Hasil Uji Reliabilitas Kuesioner Penelitian}

Uji reliabilitas dilakukan untuk mengetahui seberapa jauh hasil pengukuran tetap konsisten apabila dilakukan dua kali atau lebih terhadap gejala yang sama dengan alat ukur yang sama. Kuesioner dikatakan realibel jika nilai crobach alpha-nya > 0,6. Berdasarkan hasil data yang sudah diolah nilai cronbach alpha masing- masing variabel penelitian berada pada kisaran nilai cronbach alpha 0,6730 s/d 0,9315>0,6, untuk itu kuesioner penelitian dapat dikatakan reliabel, sehingga kuesioner penelitian ini dipercaya untuk dapat digunakan sebagai alat pengumpul data.

\section{Hasil Analisis Regresi Linier Berganda}

Hasil analisis data penelitian dengan menggunakan alat analisis regresi liner berganda diperoleh data sebagai berikut :

Tabel 2

Hasil Analisis Regresi Linier Berganda

\begin{tabular}{lccllll}
\multicolumn{7}{c}{ Coefficients $^{\mathrm{a}}$} \\
\multicolumn{1}{c}{ Model } & \multicolumn{2}{c}{$\begin{array}{c}\text { Unstandardized } \\
\text { Coefficients }\end{array}$} & $\begin{array}{l}\text { Standardized } \\
\text { Coefficients } \\
\text { B }\end{array}$ & Std. Error & t & Sig \\
\hline 1 (Constant) &, 434 & 1,141 & &, 381 &, 705 \\
Performance (X1) Feature &, 135 &, 061 &, 147 & 2,225 &, 029 \\
(X2) Reliability (X3) &, 203 &, 060 &, 197 & 3,373 &, 001 \\
Conformance (X4) &, 148 &, 052 &, 149 & 2,858 &, 005 \\
Durability (X5) &, 130 &, 053 &, 144 & 2,449 &, 017 \\
Servicebility (X6) &, 321 &, 145 &, 102 & 2,215 &, 030 \\
Aesthetics (X7) &, 099 &, 042 &, 110 & 2,389 &, 019 \\
\hline
\end{tabular}

a. Dependent Variable: Kepuasan Konsumen $(\mathrm{Y})$

Sumber : Data Primer Yang Diolah, 2020

Berdasarkan hasil analisis data pada tabel di atas dapat diuraiakan persamaan sebagai berikut:

$$
\begin{aligned}
\mathrm{Y}= & 0,434+0,135 \mathrm{X}_{1}+0,203 \mathrm{X}_{2}+0,148 \mathrm{X}_{3}+0,130 \mathrm{X}_{4}+0,321 \mathrm{X}_{5}+0,099 \mathrm{X}_{6}+ \\
& 0,165 \mathrm{X}_{7}+0,049 \mathrm{X}_{8}
\end{aligned}
$$

Nilai 0,434 adalah konstanta (a), besar nilai konstanta tersebut dapat diartikan tanpa ada variabel performance (X1), feature (X2), reliability (X3), conformance (X4), durability (X5), serviceability (X6), aesthetics $(X 7)$, dan perceived quality (X8), maka besarnya nilai kepuasan konsumen(Y) akan tetap mengalami peningkatan sebesar 0,434 satuan. Sedangkan nilai koefisien regresi untuk setiap variabel independen menunjukkan pengaruh yang positif terhadap kepuasan konsumen, artinya jika ada upaya peningkatan dimensi kualitas produk, maka kepuasan konsumen juga akan meningkat.

\section{Pengujian Hipotesis Penelitian}

Pengujian hipotesis I bertujuan untuk mengetahui pengaruh performance terhadap kepuasan konsumen Venice Pure Aesthetic Clinic Salatiga. Dengan menggunakan signifikansi 5\% pada uji dua sisi $(\alpha=0,025)$, dan degree of freedom $(n-k-1=86-8-1)=$ 77 diperoleh nilai $t_{\text {tabel }}$ sebesar 1,991. Sementara hasil analisis regresi diperoleh nilai $t_{\text {hitung }}$ sebesar 2,225. Perbandingan kedua nilai t tersebut menunjukkan nilai thitung lebih besar daripada nilai $t_{\text {tabel }}(2,225>1,991)$, berarti keputusannya menolak $H_{o}$ dan menerima $H_{a}$, ISSN : 1979-7400

E-ISSN: 2774-5163 
maka performance secara parsial berpengaruh signifikan terhadap kepuasan konsumen, sehingga hipotesis I yang menyatakan "Terdapat pengaruh signifikan performance terhadap kepuasan konsumen Venice Pure Aesthetic Clinic Salatiga" diterima.

Pengujian hipotesis II bertujuan untuk mengetahui pengaruh feature terhadap kepuasan konsumen Venice Pure Aesthetic Clinic Salatiga. Dengan menggunakan signifikansi 5\% pada uji dua sisi $(\alpha=0,025)$, dan degree of freedom $(\mathrm{n}-\mathrm{k}-1=86-8-1)=$ 77 diperoleh nilai $t_{\text {tabel }}$ sebesar 1,991. Berdasarkan hasil analisis data diperoleh nilai $t_{\text {hitung }}$

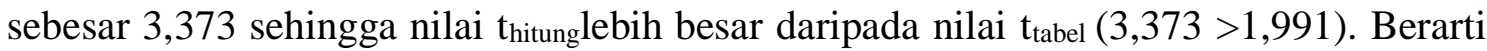
keputusannya menolak $\mathrm{H}_{\mathrm{o}}$ dan menerima $\mathrm{H}_{\mathrm{a}}$, maka feature secara parsial bepengaruh signifikan terhadap kepuasan konsumen, sehingga hipotesis II yang menyatakan "Terdapat pengaruh signifikan feature terhadap kepuasan konsumen Venice Pure Aesthetic Clinic Salatiga" diterima.

Pengujian hipotesis III dilakukan dengan tujuan untuk mengetahui pengaruh reliability terhadap kepuasan konsumen Venice Pure Aesthetic Clinic Salatiga. Dengan menggunakan signifikansi 5\% pada uji dua sisi $(\alpha=0,025)$, dan degree of freedom (n-k$1=86-8-1)=77$ diperoleh nilai $t_{\text {tabel }}$ sebesar 1,991. Berdasarkan hasil analisis data diperoleh nilai $t_{\text {hitung }}$ sebesar 2,858 sehingga nilai $t_{\text {hitung }}$ lebih besar daripada nilai $t_{\text {tabel }}$ $(2,858>1,991)$. Berarti keputusannya menolak $\mathrm{H}_{\mathrm{o}}$ dan menerima $\mathrm{H}_{\mathrm{a}}$, maka reliability secara parsial bepengaruh signifikan terhadap kepuasan konsumen, sehingga hipotesis III penelitian yang menyatakan "Terdapat pengaruh signifikan reliability terhadap kepuasan konsumen Venice Pure Aesthetic Clinic Salatiga" diterima.

Pengujian hipotesis IV ini bertujuan untuk mengetahui pengaruh conformance terhadap kepuasan konsumen Venice Pure Aesthetic Clinic Salatiga. Dengan menggunakan signifikansi 5\% pada uji dua sisi $(\alpha=0,025)$, dan degree of freedom $(n-k-$ $1=86-8-1)=77$ diperoleh nilai tabel sebesar 1,991. Berdasarkan hasil analisis data diperoleh nilai thitung sebesar 2,449 sehingga nilai thitung lebih besar daripada nilai ttabel $(2,449>1,991)$. Berarti keputusannya menolak Ho dan menerima Ha, maka conformance secara parsial bepengaruh signifikan terhadap kepuasan konsumen, sehingga hipotesis IV yang menyatakan "Terdapat pengaruh signifikan conformance terhadap kepuasan konsumen Venice Pure Aesthetic Clinic Salatiga" diterima.

Pengujian hipotesis $\mathrm{V}$ bertujuan untuk menguji pengaruh durability terhadap kepuasan konsumen Venice Pure Aesthetic Clinic Salatiga. Dengan menggunakan signifikansi 5\% pada uji dua sisi $(\alpha=0,025)$, dan degree of freedom $(n-k-1=86-8-1)=$ 77 diperoleh nilai ttabel sebesar 1,991. Berdasarkan hasil analisis data diperoleh nilai thitung sebesar 2,215 sehingga nilai thitung lebih besar daripada nilai tabel $(2,215$ $>1,991)$. Berarti keputusannya menolak Ho dan menerima Ha, maka durability secara parsial bepengaruh signifikan terhadap kepuasan konsumen, sehingga hipotesis $\mathrm{V}$ yang menyatakan "Terdapat pengaruh signifikan durability terhadap kepuasan konsumen Venice Pure Aesthetic Clinic Salatiga" diterima.

Pengujian hipotesis VI penelitian ini bertujuan untuk mengetahui pengaruh serviceability terhadap kepuasan konsumen Venice Pure Aesthetic Clinic Salatiga. Dengan menggunakan signifikansi $5 \%$ pada uji dua sisi $(\alpha=0,025)$, dan degree of freedom $(\mathrm{n}-\mathrm{k}-1=86-8-1)=77$ diperoleh nilai $\mathrm{t}_{\text {tabel }}$ sebesar 1,991. Berdasarkan hasil analisis data diperoleh nilai $t_{\text {hitung }}$ sebesar 2,389 sehingga nilai $t_{\text {hitung }}$ lebih besar daripada nilai $t_{\text {tabel }}(2,389>1,991)$. Berarti keputusannya menolak $\mathrm{H}_{\mathrm{o}}$ dan menerima $\mathrm{H}_{\mathrm{a}}$, maka serviceability secara parsial bepengaruh signifikan terhadap kepuasan konsumen, 
sehingga hipotesis VI yang menyatakan "Terdapat pengaruh signifikan serviceability terhadap kepuasan konsumen Venice Pure Aesthetic Clinic Salatiga” diterima.

Pengujian hipotesis VII ini bertujuan untuk mengetahui pengaruhaesthetics terhadap kepuasan konsumen Venice Pure Aesthetic Clinic Salatiga. Menggunakan signifikansi 5\% pada uji dua sisi $(\alpha=0,025)$, dan degree of freedom $(\mathrm{n}-\mathrm{k}-1=86-8-1)=77$ diperoleh nilai $t_{\text {tabel }}$ sebesar 1,991. Berdasarkan hasil analisis data diperoleh nilai $t_{\text {hitung }}$ sebesar 2,069 sehingga nilai $t_{\text {hitung }}$ lebih besar daripada nilai $t_{\text {tabel }}(2,069>1,991)$. Berarti keputusannya menolak $\mathrm{H}_{\mathrm{o}}$ dan menerima $\mathrm{H}_{\mathrm{a}}$, maka aesthetics secara parsial bepengaruh signifikan terhadap kepuasan konsumen, sehingga hipotesis VII yang menyatakan "Terdapat pengaruh signifikan aesthetics terhadap kepuasan konsumen Venice Pure Aesthetic Clinic Salatiga" diterima.

Pengujian hipotesis VIII bertujuan untuk mengetahui pengaruh perceived quality terhadap kepuasan konsumen Venice Pure Aesthetic Clinic Salatiga. Dengan menggunakan signifikansi $5 \%$ pada uji dua sisi $(\alpha=0,025)$ dan degree of freedom (n-k$1=86-8-1)=77$ diperoleh nilai ttabel sebesar 1,991. Berdasarkan hasil analisis data diperoleh nilai thitung sebesar 1,886 sehingga nilai thitung lebih besar daripada nilai $\mathrm{t}$ tabel $(1,886>1,991)$. Berarti keputusannya menolak Ho dan menerima Ha, maka perceived quality secara parsial bepengaruh signifikan terhadap kepuasan konsumen, sehingga hipotesis VIII yang menyatakan "Terdapat pengaruh signifikan perceived quality terhadap kepuasan konsumen Venice Pure Aesthetic Clinic Salatiga" diterima

Koefisien Determinasi (Adjusted R Square)

Koefisien determinasi menunjukkan besarnya kontribusi variabel independen, yaitu: performance $(X 1)$, feature $(X 2)$, reliability $(X 3)$, conformance $(X 4)$, durability $(X 5)$, serviceability $(X 6)$, aesthetics $(X 7)$, dan perceived quality $(X 8)$ terhadap variabel kepuasan masyarakat (Y).

Tabel 3.

Hasil Koefisien Determinasi

\begin{tabular}{lllll}
\hline Model & R & R Square & $\begin{array}{l}\text { Adjusted } \\
\text { R Square }\end{array}$ & $\begin{array}{l}\text { Std. Error of the } \\
\text { Estimate }\end{array}$ \\
\hline 1 &, $981^{\mathrm{a}}$ &, 962 &, 959 &, 48207 \\
\hline
\end{tabular}

Sumber : Data Primer Yang Diolah, 2020

Tabel di atas menunjukkan bahwa nilai Adjusted $R$ Square adalah sebesar 0,959, berarti variabel independen, yaitu performance $(X 1)$, feature $(X 2)$, reliability $(X 3)$, conformance (X4), durability (X5), serviceability (X6), aesthetics (X7), dan perceived quality $(X 8)$ mampu menjelaskan variabel dependen yaitu kepuasan konsumen(Y) sebesar $95,90 \%$. Sedang sisanya $4,10 \%$ dijelaskan oleh variabel lainnya yang tidak diteliti, seperti: biaya pelanggan, emosional pelanggan, kepercayaan produk, lokasi, dan kualitas pelayanan.

\section{PENUTUP}

Berkaitan dengan hasil penelitian ini dapat diberikan beberapa saran terhadap Venice Pure Aesthetic Clinic Salatiga, berikut penjelasannya:

Performance $\left(\mathrm{X}_{1}\right)$. Hasil penelitian menunjukkan bahwa aspek produk kecantikan yang dijual Venice Pure Aesthetic Clinic berkualitas baik, dan pelayanan yang diberikan petugas kepada konsumen berkualitas dinilai masih kurang sesuai dengan harapan sebagian konsumen. Berkaitan dengan permasalahan tersebut maka pihak manajemen Venice Pure Aesthetic Clinic Salatiga perlu lebih selektif dalam memilih produk kecantikan yang dijualnya, dan meningkatkan kemampuan petugas dalam melakukan 
pelayanan. Langkah tersebut dapat ditempuh dengan melakukan penilaian kualitas produk dan kualitas pelayanan secara berkala dengan memberikan kuesioner kepada konsumen. Melalui strategi tersebut pihak klinik dapat mengetahui apa sesungguhnya yang menjadi keluhan konsumen sehingga dapat lebih cepat mengambil tindakan untuk memperbaiknya.

Feature (X2). Hasil penelitian menunjukkan bahwa Venice Pure Aesthetic Clinic menyediakan beragam pilihan jenis produk kecantikan, dan menyediakan pilihan produk kecantikan yang sama dalam berbagai ukuran kemasan dinilai belum sesuai dengan harapan konsumen. Langkah kebijakan yang diambil oleh pihak klinik adalah lebih banyak menyediakan beragam pilihan jenis produk kecantikan, dan menyediakan pilihan produk kecantikan yang sama dalam berbagai ukuran kemasan.

Reliability (X3). Hasil penelitian menemukan bahwa konsumen tidak pernah menemukan produk kecantikan yang dibeli dari Venice Pure Aesthetic Clinic dalam kondisi cacat atau rusak, dan pelayanan yang diberikan petugas Venice Pure Aesthetic Clinic sesuai dengan yang dijanjikan masih dinilai kurang sesuai dengan harapan. Kondisi tersebut menunjukkan bahwa konsumen pernah mendapatkan produk cacat atau rusak yang dibeli, selain itu kualitas pelayanan masih dinilai kurang sesuai dengan yang dijanjikan. Berkaitan dengan temuan tersebut, langkah yang diambil manajemen klinik adalah memperbaiki sistem pengecekan produk, sementara berkaitan dengan kualitas pelayanan dapat ditempuh langkah sesuai dengan saran pada aspek performance.

Conformance (X4). Hasil penelitian menemukan bahwa terdapat sebagian konsumen yang menilai produk kecantikan yang dibeli dari Venice Pure Aesthetic Clinic belum sesuai dengan standar harapan konsumen, dan resep yang diberikan petugas (dokter) Venice Pure Aesthetic Clinic tentang penggunaan produk kecantikan belum sesuai harapan. Memperbaiki kondisi tersebut langkah yang dapat diambil oleh manajemen klinik adalah mengganti distributor produk yang lebih mampu menyediakan produk yang lebih berkualitas, sementara terkait dengan kemampuan dokter, pihak klinik mengikutkan dokter dalam pelatihan- pelatihan.

Durability (X5). Hasil penelitian menemukan beberapa orang konsumen menilai produk kecantikan yang dibeli dari Venice Pure Aesthetic Clinic saat dipakai tidak dapat bertahan selama 12 jam. Memperbaiki kondisi tersebut langkah yang dapat diambil oleh manajemen klinik adalah mengganti distributor produk yang lebih mampu menyediakan produk yang lebih berkualitas.

Serviceability (X6). Hasil penelitian menemukan terdapat konsumen yang menilai petugas Venice Pure Aesthetic Clinic dinilai kurang ramah. Berkaitan dengan temuan tersebut pihak klinik dapat melakukan langkah-langkah seperti: sebelum pekerjaan dimulai pihak manajer klinik perlu mengadakan pertemuan singkat kepada seleuruh petugas dalam rangka memberikan beberapa masukan kepada petugas dalam melaksanakan pekerjaannya.

Aesthetics (X7). Hasil penelitian menemukan bahwa aspek produk kecantikan yang ditawarkan oleh Venice Pure Aesthetic Clinic dalam kondisi selalu bersih dinilai sebagian konsumen belum sesuai harapan. Memperbaiki kondisi tersebut langkaH yang dapat ditempuh pihak manajer klinik adalah merubah sistem dalam pengecekan produk agar produk yang dibeli oleh konsumen terjaga kebersihannya.

Perceived Quality (X8). Hasil penelitian menemukan terdapat beberapa orang responden yang menilai bahwa kualitas produk kecantikan yang dibeli dari Venice Pure Aesthetic Clinic sesuai dengan manfaatnya. Memperbaiki kondisi tersebut langkah yang dapat diambil oleh manajemen klinik adalah mengganti distributor produk yang lebih mampu menyediakan produk yang lebih berkualitas.

Bagi penelitian yang akan datang yang tertarik untuk melakukan penelitian kepuasan konsumen pada objek yang sama, ada baiknya menambah variabel penelitian seperti: 
harga produk kecantikan, harga perawatan kecantikan, kepercayaan produk, lokasi, dan kualitas pelayanan untuk menyempurnakan hasil penelitian di Venice Pure Aesthetic Clinic.

\section{DAFTAR PUSTAKA}

Amir, M. 2018. Pengaruh Kualitas Produk Terhadap Kepuasan Konsumen Pengguna Notebook Acer Pada PT. Genius Alva Makassar. diakses dari https://www.stienobelindonesia.ac.id.

Annishia, F. B., dan Setiawan, M. S., 2018. Pengaruh Kualitas Produk Kopi Terhadap Kepuasan Konsumen di Jade Lounge Swiss-Belresidences Kalibata Jakarta. Jurnal Hospitality dan Pariwisata, Vol.4, No. 1, (Tahun 2018), hal. 60-69.

Ariani, D. W. 2003. Manajemen Kualitas: Pendekatan Sisi Kualitatif. Proyek Peningkatan Penelitiaan Pendidikan Tinggi Direktoran Jendral Pendidikan Tinggi Depdiknas.

Ariani, D. Wahyu. 2009. Manajemen Operasi Jasa. Edisi Pertama. Yogyakarta: Graha Ilmu.

Arikunto, S. 2006. Metode Penelitian Kualitatif. Jakarta: Bumi Aksara.

Basith, Abdul, Kumadji, Srikandi dan Hidayat Kadarisman. 2014. Pengaruh Kualitas Produk dan Kualitas Pelayanan Terhadap Kepuasan Pelanggan dan Loyalitas Pelanggan. Jurnal Administrasi Bisnis. Vol. 11 No.1.

Daft, L. Richard. 2012. Era Baru Manajemen. Edisi Kesembilan. Jakarta: Salemba Empat.

Hasan, Iqbal. 2004. Analisis Data Penelitian Dengan Statistik. Bumi Aksara, Jakarta.

Hayati, Y. H., 2015. Pengaruh Kualitas Produk Terhadap Kepuasan Konsumen di Restoran Bebek dan Ayam Goreng Pak Ndut Solo. JIMFE (Jurnal Ilmiah Manajemen Fakultas Ekonomi), Vol 1, No. 1 (Tahun 2015), hal. 49-56.

Hery. 2013. Pengantar Manajemen. Jakarta: Gava Media.

Kotler, Philip and Kevin Lane Keller, 2009. Manajemen Pemasaran. PT. Indeks, Jakarta.

Kotler, Philip, 2018. Manajemen Pemasaran. PT. Erlangga, Jakarta.

Nasution, 2010. Manajemen Mutu Terpadu. Ghalia Indonesia, Bogor Selatan.

Pride, William M. and O.C. Ferrell, 2010. Marketing. South Western International Edition, Canada.

Sanusi, Anwar. 2011. Metodologi Penelititian Bisnis. Jakarta Selatan: Salemba Empat

Sudaryono. 2015. Pengantar Bisnis - Teori dan Contoh Kasus. Yogyakarta: C.V Andi Offset

Sugiyono. 2012. Metode Penelitian Kombinasi. Bandung: Alfabeta.

Sugiyono, 2016. Metode Penelitian Kuantitatif, Kualitatif dan R\&D. Bandung: PT

Alfabet.

Suparyanto \& Rosad. 2015. Manajemen Pemasaran, In Media, Yogyakarta.

Supramono dan Sugiarto, 2003. Statistika. Andi Offset, Yogyakarta.

Supranto, J, 2006. Pengukuran Tingkat Kepuasan Pelanggan untuk Menaikkan Pangsa

Pasar. PT. Rineka Cipta, Jakarta.

Tjiptono, Fandy, 2016. Pemasaran Jasa. Andi Offeset, Yogyakarta.

Umar, Husein. 2002. Metode Penelitian dan Aplikasi dalam Pemasaran. Jakarta: PT. Gramedia Pustaka Umum.

Widiyanto, Ibnu. 2008. Metodologi Penelitian. Semarang: Badan Penerbit Undip 
